\title{
The impacts of product market competition on the quantity and quality of voluntary
} disclosures

\author{
Mojgan Saeidi ${ }^{a}$, Fatemeh Saraf ${ }^{b^{*}}$ and Mohsen Hamidian
}

${ }^{a}$ Masters studend, South Tehran Branch, Islamic Azad University, Tehran, Iran

${ }^{b}$ Faculty member, South Tehran Branch, Islamic Azad University, Tehran, Iran

\begin{tabular}{|c|c|}
\hline C H R O N I C L E & A B S T R A C T \\
\hline $\begin{array}{l}\text { Article history: } \\
\text { Received January 20, } 2015 \\
\text { Received in revised format } 16 \\
\text { February } 2015 \\
\text { Accepted } 12 \text { April } 2015 \\
\text { Available online } \\
\text { April } 142015 \\
\text { Keywords: } \\
\text { Tehran Stock Exchange } \\
\text { Product market competition } \\
\text { Voluntary disclosures }\end{array}$ & $\begin{array}{l}\text { This paper presents an empirical investigation to study the relationship between product market } \\
\text { competition and voluntary disclosure among } 124 \text { selected firms listed on Tehran Stock } \\
\text { Exchange over the period 2004-2013. The study uses Herfindahl-Hirschman Index (HHI) and } \\
\text { Lerner (LLIA) index to measure competition in terms of capacity and price, respectively. In } \\
\text { addition, the study uses the questionnaire developed by Botosan (1997) [Botosan, C. A. (1997). } \\
\text { Disclosure level and the cost of equity capital. Accounting Review, 72(3), 323-349.] to measure } \\
\text { voluntary disclosure. Using linear regression technique, the study has determined that there } \\
\text { was a meaningful, direct and positive relationship between voluntary disclosure and } \\
\text { competition in terms of price (LLIA). In addition, the results indicate that there was a } \\
\text { meaningful and reverse relationship between voluntary disclosure and competition in terms of } \\
\text { capacity (HHI). }\end{array}$ \\
\hline
\end{tabular}

\section{Introduction}

Many previous studies have argued that companies active in the capital market, are more willing to disclose information (Lang \& Lundholm, 1993, 2000; Frankel et al., 1995; Healy et al., 1999; Healy \& Palepu, 2001; Datta et al., 2013; de La Bruslerie \& Gabteni, 2014). Therefore, managers usually try to provide more information and better understanding of the company's performance for external people, even in an efficient capital market (Francis et al., 2008). Voluntary disclosure strategy plays a major role in reducing information asymmetry between managers and external investors (Shin, 2002). Proprietary information is the primary source of information asymmetry (Shin, 2013). Disclosure of confidential information is costly because existing and potential competitors may take advantage of the company's strategic information in their product markets (Shin, 2013). Therefore, companies must achieve a balance between the benefits of voluntary disclosure and protecting the long-term benefits of their product market. According to Shin (2013) existing competition may discourage companies to disclose information, but the competition itself can be an effective factor in making decision to disclose

* Corresponding author.

E-mail address: aznyobe@yahoo.com (F. Saraf) 
information. According to Theory of Industrial Organization and Kreps and Scheinkman (1983), most firms make strategic decisions based on the principle of two-stage game: they first independently select their desired capacities and then consider other firms' capacities for product development. There are two different strategies associated with the disclosure of information: first, the competition from the perspective of capacity, which in turn is driving companies to disclose more information. The second strategy is associated with price, which has a reverse relationship with voluntary disclosure strategy.

Kwak et al. (2012) examined whether the composition of top management with General Counsel (GC) could influence on properties of management earnings forecasts disclosures. After controlling for corporate governance and litigation risk, they reported that firms with a GC in top management tend to issue forecasts, particularly bad news forecasts, than other firms. In addition, their forecasts could be less optimistic and more accurate than those issued by others. The stock price reaction also to their forecast news was stronger. These effects were more pronounced when the GC's managerial status was higher. Chen et al. (2012) investigated the relationship between product market competition and normal related party transactions and reported a positive relationship. Besides, they studied the substitutive impact of product market competition and the cash flow rights owned by final controlling shareholders on the extent of normal related party transactions. They recommended a positive relationship between the ultimate controlling shareholders' cash flow rights and normal related party transactions, which was strongest in noncompetitive industries and weakens as product market competition increases.

Cheng et al. (2006) reported new evidence that companies with a higher proportion of independent directors on the board were somehow related to higher levels of voluntary disclosure. Although board size and CEO duality were not related to voluntary disclosure, boards with a majority of independent directors maintained substantially higher levels of voluntary disclosure than companies with balanced boards. Moreover, they reported that the presence of an external governance mechanism, the regulatory environment, could enhance the strength of the association between the proportion of independent directors and the level of voluntary disclosure. This association was some two to three times bigger under a "disclosure-based” regulatory regime than under a "merit-based” regulatory regime.

Cheng et al. (2013) investigated the effect of product market competition on earnings quality. They reported consistent evidence indicating a positive relationship between product market competition and earnings quality based on a sample from the US manufacturing sector over the period 1996-2005. Additional investigation also confirmed a positive relationship between product market competition and the precision of public and private information held by investors. Moreover, they provided some evidence that companies competing in concentrated and heterogeneous industries were associated with a number of earnings attributes and information quality not shared by those competing in concentrated but homogeneous industries.

Collett and Hrasky (2005) studied the relationship between the voluntary disclosure of data about corporate governance practices and the intention to raise external finance. This relationship was studied by using corporate governance disclosures in the annual reports of Australian companies in 1994. Data from this year were implemented because in subsequent years Australian Stock Exchange regulations affected listed firms to make disclosures about their corporate governance practices. They reported that the voluntary disclosure of corporate governance information was positively associated with the intention to raise equity capital, but not with the intention to raise debt capital.

\section{The proposed study}

This paper presents an empirical investigation to study the relationship between product market competition and voluntary disclosure among 124 selected firms listed on Tehran Stock Exchange over the period 2004-2013. The study uses Herfindahl-Hirschman Index (HHI) and Lerner index Lerner (1934) to measure competition in terms of capacity and price, respectively. In addition, the study uses 
the questionnaire developed by Botosan (1997) to measure voluntary disclosure. The HerfindahlHirschman Index (HHI) considers the size of firms in relation to the industry and an indicator of the amount of competition among them in terms of capacity. The proposed study of this paper uses HHI as independent variable. In addition, the study uses competition in terms of price by Lerner index (LIIA) as follows,

$$
\text { LI = (Sale - Cogs - SG \& A) / Sale, }
$$

where Sale, Cogs, SG \& A represent sales, cost of goods and administration expenses, respectively. In this survey, voluntary disclosure (VD) is considered as dependent variable. Finally, the present study uses size of firm (Size), debt ratio (Lev) and return on assets (ROA) as control variables. The study considers the following two regression equations,

$$
\begin{aligned}
& \mathrm{VD}=\alpha+\beta_{1} \text { HHI }+\beta_{2} \text { Size }+\beta_{3} \text { Lev }+\beta_{4} \mathrm{ROA}+\varepsilon, \\
& \mathrm{VD}=\alpha+\beta_{1} \text { LIIA }+\beta_{2} \text { Size }+\beta_{3} \text { Lev }+\beta_{4} \mathrm{ROA}+\varepsilon .
\end{aligned}
$$

As stated before, 124 firms listed on Tehran Stock Exchange over the period 2004-2013 have been considered to examine the relationship between voluntary disclosure (VD) and Herfindahl-Hirschman Index (HHI) and Lerner index (LIIA). Table 1 demonstrates the summary of some basic statistics.

\section{Table 1}

The summary of some basic statistics on dependent, independent and control variables

\begin{tabular}{ccccccc}
\hline Variable & Min & Max & Mean & Standard deviation & Skewness & Kurtosis \\
\hline HHI & 0.005 & 1 & 0.219 & 0.241 & 2.079 & 4.645 \\
LIIA & -0.061 & 0.772 & 0.184 & 0.158 & 1 & 0.595 \\
VD & 0.134 & 0.500 & 0.332 & 0.075 & -0.173 & 0.300 \\
Size & 9.283 & 18.064 & 13.876 & 1.582 & 0.285 & 0.230 \\
Lev & 0.036 & 1.455 & 0.647 & 0.311 & 0.340 & -0.497 \\
ROA & -0.120 & 0.778 & 0.180 & 0.136 & 1.286 & 3.962 \\
\hline
\end{tabular}

In addition, Table 2 presents the summary of correlations among different independent, dependent and control variables and the results indicate that there would not a serious correlation.

Table 2

The summary of the correlations among different pairs of the variables

\begin{tabular}{ccccccc}
\hline & HHI & LIIA & VD & Size & Lev & ROA \\
\hline HHI & 1 & & & & & \\
LIIA & $-0.466(0.0005)$ & 1 & & & & \\
VD & $-0.359(0.0005)$ & $0.335(0.0005)$ & 1 & & & \\
Size & $-0.156(0.084)$ & $0.199(0.027)$ & $0.345(0.0005)$ & 1 & 1 & \\
Lev & $-0.124(0.170)$ & $0.145(0.109)$ & $0.384(0.0005)$ & $0.354(0.0005)$ & 1 \\
ROA & $0.026(0.776)$ & $-0.176(0.050)$ & $-0.072(0.425)$ & $-0.045(0.619)$ & $0.046(0.615)$ & 1 \\
\hline
\end{tabular}

Next, we need to use unit root test regression technique to verify whether the data are stationary or not. This is accomplished using the methods offered by Levin et al. (2002), Im et al. (1997), Dickey and Fuller (1981) and Phillips and Xiao (1998). The results indicate that all data were stationary and we may therefore perform the regression technique.

\section{Table 3}

The summary of unit root test using different techniques

\begin{tabular}{lcccc}
\hline Variable & $\begin{array}{c}\text { Levin (Levin et al. } \\
(2002)\end{array}$ & Im et al. (1997) & $\begin{array}{c}\text { Augmented Dickey-Fuller } \\
\text { (Dickey \& Fuller, 1981) }\end{array}$ & $\begin{array}{c}\text { Philips-Perron, (Phillips, \& } \\
\text { Xiao, 1998) }\end{array}$ \\
\hline HHI & $-275.138(0.00005)$ & $-25.0789(0.0005)$ & $500.316(0.0005)$ & $630.671(0.00005)$ \\
LIIA & $-21.0094(0.00005)$ & $-9.32403(0.0005)$ & $572.799(0.0005)$ & $732.909(0.0005)$ \\
Size & $-31.0953(0.0005)$ & $-12.5169(0.0005)$ & $657.047(0.0005)$ & $814.663(0.0005)$ \\
Lev & $-181.880(0.0005)$ & $-30.3615(0.0005)$ & $715.204(0.0005)$ & $837.305(0.00005)$ \\
ROA & $-23.3062(0.00005)$ & $-10.1993(0.0005)$ & $574.584(0.00005)$ & $717.944(0.0005)$ \\
\hline
\end{tabular}


Finally, the results of VIF test are presented in Table 4. As we can observe from the results of Table 4, there is no linear regression among independent variables.

Table 4

The results of VIF test

\begin{tabular}{lccccc}
\hline & HHI & LIIA & Size & Lev & ROA \\
\hline HHI model & 1.031 & - & 1.164 & 1.155 & 1.007 \\
LIIA model & - & 1.082 & 1.175 & 1.158 & 1.039 \\
\hline
\end{tabular}

\section{The results}

In this section, we present the results of the implementation of regression techniques on Eq. (2) and Eq. (3). We first present the results of the regression on Eq. (2) as follows,

$\begin{array}{lrlccc} & \text { VD }=0.184 & -0.091 & \mathrm{HHI} & +0.009 & \text { Size }+0.068 \mathrm{Lev}-0.038 \mathrm{ROA} \\ \text { Standard deviation } & 0.055 & 0.025 & 0.004 & 0.020 & 0.043 \\ \text { t-value } & 3.373 & -3.701 & 2.364 & 3.371 & -0.883 \\ \text { Sig. } & 0.001 & 0.00005 & 0.020 & 0.001 & 0.993\end{array}$

Adjusted R-Square $=0.261$ Durbin-Watson $=2.033$ F-Value $=11.882(0.0005)$

Kolmogorov-Smirnov $(\mathrm{Z}=0.903$ P-value $=0.389)$

As we can observe from the results of our survey, all statistical observations maintain meaningful tvalue when the level of significance is five percent. In addition, Durbin-Watson value is equal to 2.033, which means there is no auto-correlation among residuals. Moreover, Kolmogorov-Smirnov test indicates that the data were normally distributed and adjusted R-Square indicates that the independent variables could describe $26 \%$ of the changes on dependent variable. According to the results of Eq. (4), there is a meaningful and negative relationship between HHI index and VD. In addition, we present details of our findings on testing Eq. (3) and the results are summarized in Eq. (5) as follows,

$\begin{array}{lrrrrr} & \text { VD }=0.140+0.119 & \text { LIIA }+0.009 & \text { Size }+0.068 \text { Lev }-0.018 \text { ROA } \\ \text { Standard deviation } & 0.054 & 0.039 & 0.004 & 0.021 & 0.044 \\ \text { t-value } & 2.597 & 3.051 & 2.286 & 3.300 & -0.400 \\ \text { Sig. } & 0.011 & 0.003 & 0.024 & 0.001 & 0.962\end{array}$

Adjusted R-Square $=0.236$ Durbin-Watson $=2.11$ F-Value $=10.505(0.0005)$

Kolmogorov-Smirnov $(\mathrm{Z}=0.916 \mathrm{P}$-value $=0.371)$

As we can see from the results, all statistical observations maintain meaningful t-value when the level of significance is five percent. In addition, Durbin-Watson value is equal to 2.11, which means there is no auto-correlation among residuals. Moreover, Kolmogorov-Smirnov test indicates that the data were normally distributed and adjusted R-Square indicates that the independent variables could describe $24 \%$ of the changes on dependent variable. According to the results of Eq. (5), there is a meaningful and positive relationship between LIIA index and VD. This is consistent with findings of Gietzmann and Ireland (2005), Chen et al. (2012) and Collett and Hrasky (2005).

\section{Conclusion}

In this paper, we have presented an empirical investigation to study the relationship between product market competition and voluntary disclosures on firms listed on Tehran Stock Exchange. The proposed study has implemented two regression techniques and determined that there was meaningful and positive relationship between Lerner index and voluntary disclosures. In addition, the study has detected a negative relationship between Herfindahl-Hirschman Index and voluntary disclosures. The results of our study are consistent with other findings in the literature as stated earlier. 


\section{Acknowledgement}

The authors would like to thank the anonymous referees for constructive comments on earlier version of this paper.

\section{References}

Botosan, C. A. (1997). Disclosure level and the cost of equity capital. Accounting Review, 72(3), 323349.

Chen, S., Wang, K., \& Li, X. (2012). Product market competition, ultimate controlling structure and related party transactions. China Journal of Accounting Research, 5(4), 293-306.

Cheng, E. C., \& Courtenay, S. M. (2006). Board composition, regulatory regime and voluntary disclosure. The international journal of accounting, 41(3), 262-289.

Cheng, P., Man, P., \& Yi, C. H. (2013). The impact of product market competition on earnings quality. Accounting \& Finance, 53(1), 137-162.

Collett, P., \& Hrasky, S. (2005). Voluntary disclosure of corporate governance practices by listed Australian companies. Corporate Governance: An International Review, 13(2), 188-196.

Datta, S., Iskandar-Datta, M., \& Singh, V. (2013). Product market power, industry structure, and corporate earnings management. Journal of Banking \& Finance, 37(8), 3273-3285.

Dickey, D. A., \& Fuller, W. A. (1981). Likelihood ratio statistics for autoregressive time series with a unit root. Econometrica: Journal of the Econometric Society, 49(4), 1057-1072.

Frankel, R., McNichols, M., \& Wilson, G. P. (1995). Discretionary disclosure and external financing. Accounting Review, 70(1), 135-150.

Francis, J., Nanda, D., \& Olsson, P. (2008). Voluntary disclosure, earnings quality, and cost of capital. Journal of accounting research, 46(1), 53-99.

Gietzmann, M., \& Ireland, J. (2005). Cost of capital, strategic disclosures and accounting choice. Journal of Business Finance \& Accounting, 32(3-4), 599-634.

Healy, P. M., Hutton, A. P., \& Palepu, K. G. (1999). Stock performance and intermediation changes surrounding sustained increases in disclosure. Contemporary accounting research, 16(3), 485-520.

Healy, P. M., \& Palepu, K. G. (2001). Information asymmetry, corporate disclosure, and the capital markets: A review of the empirical disclosure literature. Journal of accounting and economics, 31(1), 405-440.

Im, K. S., \& Pesaran, M. H. Y. Shin (1997):“Testing for Unit Roots in Heterogeneous Panels”. Cambridge: University of Cambridge.

Kreps, D. M., \& Scheinkman, J. A. (1983). Quantity precommitment and Bertrand competition yield Cournot outcomes. The Bell Journal of Economics, 326-337.

Kwak, B., Ro, B. T., \& Suk, I. (2012). The composition of top management with general counsel and voluntary information disclosure. Journal of Accounting and Economics, 54(1), 19-41.

Lang, M., H., \& Lundholm, R. (1993). Cross-sectional determinants of analyst ratings of corporate disclosures. Journal of accounting research, 31(2), 246-271.

Lang, M. H., \& Lundholm, R. J. (2000). Voluntary Disclosure and Equity Offerings: Reducing Information Asymmetry or Hyping the Stock?. Contemporary Accounting Research, 17(4), 623662.

de La Bruslerie, H., \& Gabteni, H. (2014). Voluntary disclosure of financial information by French firms: Does the introduction of IFRS matter?. Advances in Accounting, 30(2), 367-380.

Lerner, A. P. (1934). The concept of monopoly and the measurement of monopoly power. The Review of Economic Studies, 1(3), 157-175.

Levin, A., Lin, C. F., \& Chu, C. S. J. (2002). Unit root tests in panel data: asymptotic and finite-sample properties. Journal of Econometrics, 108(1), 1-24.

Phillips, P. C., \& Xiao, Z. (1998). A primer on unit root testing. Journal of Economic Surveys, 12(5), 423-470. 
Shin, Y. C. (2002). The effect of product market competition on corporate voluntary disclosure decisions. Available at SSRN 338361.

Shin, Y. C. (2013). Voluntary disclosure and the type of product market competition: Capacity vs. Price. Journal of Modern Accounting and Auditing, 9(4), 505-526. 